DOI: $10.1515 /$ rpp-2015-0064

Doctor of Pedagogical Sciences, Full Professor, OKSANA ZABOLOTNA Pavlo Tychyna Uman State Pedagogical University, Ukraine Address: 2 Sadova St., Cherkasy Region, Uman, 20300, Ukraine E-mail: oxana.zabolotna@gmail.com

\title{
ACADEMIC MOBILITY PROJECTS MANAGEMENT: CHALLENGES FOR UKRAINIAN PROFESSIONAL EDUCATION
}

\begin{abstract}
The article is devoted to the academic mobility projects management on the example of Pavlo Tychyna Uman State Pedagogical University in the Erasmus Mundus Projects, namely, EMINENCE and EMINENCE II. It has been pointed out that modern university is a constantly developing system possessing a hidden potential for innovations. Thus, the significance of international projects has been justified as they are the way for using the opportunities. And they have also been considered the means of funding research through collaboration and academic mobility. The description of EMINENCE and EMINENCE II has been given. The author stresses that the EMINENCE idea is that only through multiplication and spreading of gained abroad benefits the mobility of project participants will have wider impact on the capacity of sending partners. The responsibilities of PTUSPU performing the function of Joint-Coordinator within the projects have been enumerated and commented on. It has been mentioned by the author that twenty four representatives of PTUSPU have participated in the academic mobility hosted by European Universities. The statistical information illustrating the above given information has also been presented. The levels presupposed by the system of preparing for managing international projects have been listed, namely cultural, organizational, management and economic level. The characterization of each of these levels has been given. Different project phases such as pre-selection, selection, mobility and post-mobility periods have been described. In terms of description of the selection stage, the panels of EMINENCE Selection Committee along with their responsibilities have been listed. The number of challenges associated with international projects management, faced by Ukrainian professional education has been mentioned and emphasized.
\end{abstract}

Key words: international projects, EMINENCE, academic mobility, funding, PTUSPU.

\section{INTRODUCTION}

With the new Law on Higher education in Ukraine universities got more autonomy, that is more freedom through the ability to independently decide at such levels as organizational, staffing, academic and financial ones. According to European University Association (EUA) "organizational autonomy refers to a university's ability to decide freely on its internal organization" (EUA, 2015). Staffing autonomy refers to a university's ability to decide freely on issues related to human resources management, including recruitments, salaries, dismissals and promotions (EUA, 2015). Academic autonomy refers to a university's capacity to manage its internal academic affairs independently (EUA, 2015). Financial autonomy refers to a university's ability to decide freely on its internal financial affairs (EUA, 2015).

Nevertheless, even after a year it became quite clear that what the autonomy gives with one hand, the lack of funding takes with the other. There is a contradiction which is to 
be solved through finding alternative sources of support to research, academic programmes and staff professional development. Global economy has brought Ukrainian universities to understanding that they are to change their positions at the global educational market. That means that Ukrainian research and innovation are to be viewed against the background of global ones. Even some glimpses of that may give the realization that in many academic fields Ukraine falls far behind the leading world's universities.

That is why a greater importance is being drawn to international projects as the means of funding research through collaboration and academic mobility. On the one hand, they might meet the challenge of insufficient public funding; on the other hand, they will assist in understanding the global needs and meeting the global standards.

\section{THE AIM OF THE STUDY}

The aim of the study is to analyze the current possibilities of grant rising for Ukrainian universities and to suggest the model of academic mobility project management resulting from empirical research of the process at Pavlo Tychyna Uman State Pedagogical University.

\section{THEORETICAL FRAMEWORK AND RESEARCH METHODS}

The article relies on the scope of theoretical works of the university autonomy, comparative educational research on grant rising in American and European universities, on international project management, materials on Erasmus + , as well as a 10-year experience of managing international projects at Pavlo Tychyna Uman State Pedagogical University (Ukraine).

For reaching the purpose of the article the author has used some theoretical (analysis, description and comparison) and empirical methods by means of direct and indirect observation or experience.

\section{RESULTS}

Modern university is a constantly developing system possessing a hidden potential for innovations. International projects constitute the way for using the opportunities. The analysis of the current situation with international collaboration of Ukrainian universities demonstrates that the major problem is in the absence of efficient project management (Brin, 2014).

There is a distinction between international research projects and academic mobility projects. That is because in spite of the fact that their primary goals are the same, the steps to achieve them are somewhat different. If an international research project sees academic mobility as a means to bring academics from different partner countries together, academic mobility projects aim at bringing scholars together as a starting point for collaborative research.

Thus, Pavlo Tychyna Uman State Pedagogical University has been engaged in 2 Erasmus Mundus projects (EMINENCE and EMINENCEII) as a joint coordinator, where EMINENCE is Erasmus Mundus Integration of Neighbouring EasterN Regions through Cooperation in Higher Education. The acronym of the project brings a message that the project targets at "eminence", understood as distinction, reputation and importance of future project beneficiaries on their return to EaP societies - so needed for the development of countries aspiring to reach European standards (EMINENCE, 2015).

Both projects are built on partnerships of 20 universities from European Union (HEIs from France, Poland, Portugal, Romania, Spain, Sweden) and Eastern neighbouring regions (HEIs from Armenia, Azerbaijan, Belarus, Georgia, Moldova and Ukraine). The projects have offered scholarships for students (undergraduate, master, doctoral and postdoctoral) and for staff (academic and administrative) to be awarded for both sides candidates (EMINENCE management, 2015).

The EMINENCE idea is that only through multiplication and spreading of gained abroad benefits (knowledge, skills, experience, ideas, scientific resources etc.) their 
mobility will have wider impact on the capacity of sending partners. That is why the project will introduce obligatory post-mobility phase - students and staff after return will play a role of transmitters and multipliers of gained benefits - with obligatory "transfer of knowledge, skills and ideas phase" (called "POST-MUNDUS TOK") after completion of mobility period that will be organized by returnees together with their home universities. According to the agreement Pavlo Tychyna Uman State Pedagogical University performs the functions of joint-coordinator with the following responsibilities:

- supporting role for the other Eastern neighbouring partners in the regioncollecting original documents of TG $2 / 3$ candidates, checking their accuracy and oneness with scans submitted in online data base and then sending them to AMU, validation of TG 2/3 candidates;

- correspondence with beneficiaries about organization of mobility, contacts with local EC delegations, ministries, embassies (for promotion at the start of the project);

- monitoring and collection of records concerning promotion events organized by all Ea Partners during recruitment;

- planning communication and visibility strategy: collection of ideas of dissemination activities of wider impact - possibilities of participation in events like fairs and conferences, communications and articles to media.

PTUSPU as joint coordinator collected records concerning promotion events organized by all Ea Partners during recruitment in 2012-2015 in terms of events (conferences, seminars, exhibitions etc.) and materials published. The information of the organized events included details of the title, venue, participating target groups, number of participants. It was also reinforced by photo and video materials. The EaP as well as EU partners also share published promotion in their scanned versions as well as links to webpages where they could be found.

Planning communication and visibility strategy by joint coordinator underwent several stages: collecting ideas of dissemination activities of wider impact from partner universities; presenting the ideas for the visibility strategy at the coordinators' meeting, discussing their strengths, weaknesses, opportunities and threats; participating in the election of communication and visibility committee members ( 5 people) for monitoring possibilities of participation in events like fairs and conferences, communications and articles to media.

For the years that the partners have been in the project the academic community of the partner universities have come closer in understanding common goals and have made the first steps to bilateral cooperation which is necessary for participating in ERASMUS+.

24 representatives of Pavlo Tychyna Uman State Pedagogical University have participated in the academic mobility hosted by Adam Mickiewicz University of Poznan (Poland), University of Montpellier (France), University of Porto (Portugal), as well as Malmo University (Sweden) and Rovira i Virgili University (Spain) (see Table 1).

Table 1

Mobility Flows between PTUSPU and EU Partner Countries within EMINENCE and EMINENCE II Erasmus Mundus Projects

\begin{tabular}{|c|c|c|c|c|c|}
\hline Years & Undergraduates & Doctorates & Post-doctorates & Staff & Total \\
\hline $2013-14$ & 1 & 1 & 1 & - & 3 \\
\hline $2014-15$ & 3 & 1 & 1 & 2 & 7 \\
\hline $2015-16$ & 6 & 4 & 3 & 1 & 14 \\
\hline Total & 10 & 6 & 5 & 3 & 24 \\
\hline
\end{tabular}


It should be mentioned that the level of competitiveness was rather high even for target group 1 (3/5:1). The system of preparing for managing international projects presupposed several levels: cultural level, aiming at familiarizing with the cultural peculiarities of the prospective partner country, where the stress is put on the intercultural communication issues; organizational level, emphasizing the importance of special training for international events; management level, having in its core the principles of realizing international educational projects, their managing and evaluation; economic level, targeting at budget management peculiar to EU operations with funds and being quite challenging in current academic conditions (see Fig. 1).

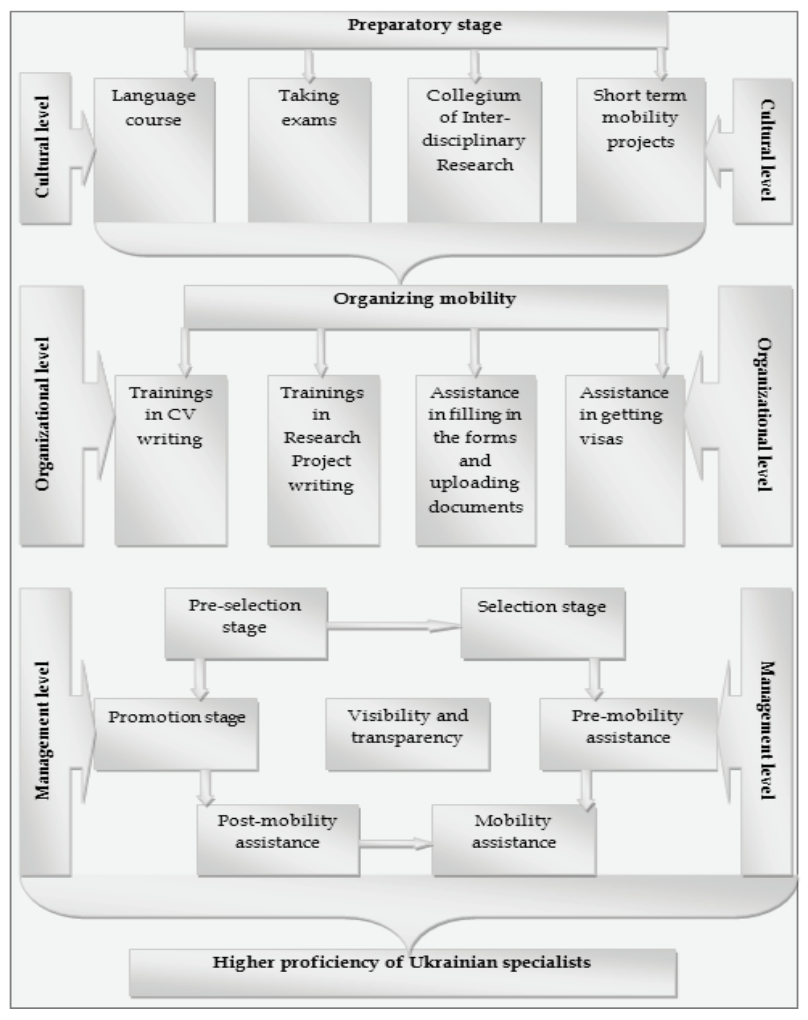

Fig. 1

At the cultural level the main stress was laid on several organized activities. The first one was connected with studying and research at the Collegium of International Interdisciplinary Studies in Humanities which functions in the university structure. This one was especially efficient not only with the students majoring in the Humanities, but also with those studying Sciences. There is a visible gap between what the host universities propose for candidates who major in sciences and those who major in humanities with the stress laid on the former ones. The problem is that they often prove uncompetitive because of their low level of language proficiency, that is why the Collegium can increase their chances.

After the careful selection (application forms and interview) the students were admitted to the Collegium where, in addition to their main studies, they might become proficient 
users of foreign languages (with English and Polish being obligatory courses). Besides, they mastered the methodology of interdisciplinary research, which was aimed at intercultural issues.

The other way of helping the candidates to cross the barriers on their way to the desired academic mobility was the special intensive course of preparing for international exams (mainly IELTS and TOFL). The 100 hour programme was available for undergraduate students, PhD students, post-docs and staff members.

At the organizational level, a series of trainings was suggested to all the categories of candidates. They dealt with different issues, starting with CV writing and course selection and finishing with the tips to write an efficient research project. The skills in the latter were especially important for $\mathrm{PhD}$ students and post-docs, who were to submit the research proposal, provisionally finding research team or research supervisor at a partner university. Individual consultancy was of great importance as well, as it helped to meet individual needs and avoid pitfalls that might reduce the chances for winning the mobility grant. At the management level the main attention was paid to the communication with partners and candidates / grantees at different project phases (pre-selection, selection, mobility and post-mobility periods).

The pre-selection stage implies carrying on open and well-announced recruitment for TG 1, 2 and 3, disseminating by this occasion programme and project content and objectives, using information in English to be placed on EaP partners' websites and disseminating information about the project in local languages, using other possible communication channels, before the call for applications is opened. With TG1 candidates the most effective events are meetings with the scholarship holders who have come back to their home universities. TG2 candidates are better reached through the participation in international conferences, seminars and exhibitions, as well as publishing promotional materials on university websites, in academic periodicals and other mass media. Another aspect of managing the project before the selection starts is group and individual consultancy as to the way application form is filled in, host universities are chosen, documents are submitted. That is extremely important, as the project quality depends on how efficient the grantees are, which can be evaluated only by the submitted documents of high-quality.

At the selection stage, the submitted documents undergo some stages of evaluation: by home university, by coordinator / joint-coordinator, by host university and by the selection committee. This multi-layered evaluation ensures transparency and impartiality in the selection of scholarship holders. Partners are obliged to carry on collective procedures of pre-selection of best appropriate students candidates to target group 1 and 3 and to rank them by marking in intranet recommendations for selection concerning the best student candidates thus confirming their checked and assured eligibility, language ability and reliability of their documents. In case of TG3 candidates EaP partners are to facilitate recruitment and preparation in cooperation with associates and other bodies, as well as initiating any other possible measures to find proper candidates fulfilling formal criteria of TG 3 beneficiaries (EMINENCE Selection Process, 2015).

Selection Committee of EMINENCE consists of 15 panels at each EaP partner which did pre-selection of candidates: eligibility check and quality assessment based on original documents, submission of pre-selection evaluation forms, reports, staff mobility assignments based on bilateral agreements; 5 panels at each EU partner that did candidates' pre-selection: eligibility check and quality assessment based on electronic version of candidates' documents, submission of pre-selection evaluation forms, reports, staff mobility assignments based on bilateral agreements; eligibility check by AMU eligibility check panel 
based on original documents sent by candidates; Final Selection Committee, which role is verification of previous eligibility check based on original documents, ranking of candidates and allocation to selected and reserve list, according to ranking, project budget for implementation of mobility and contractual quota concerning study levels, target groups, nationality, considering cross-cutting issues (gender-balance, equal opportunities and the participation of disadvantaged groups), balanced distribution of mobility within partnership etc.

After the selection comes the stage of organising mobility which implies agreeing and proceeding learning agreements of selected students, supporting, if necessary their application for visas, in case of TG 1 and 3 - informing the coordinator of the project when the visa is issued, as the condition for purchasing the ticket. Some actions may require carrying out academic recognition procedures of periods of study, training, research and teaching of their students and staff after return. It should be pointed out that full recognition of periods of studies abroad as integral parts of their studies at home is important. Otherwise the mobility abroad can be the reason to make regular period of students' studies at home longer or require additional exams.

During the mobility period the consortium members have to introduce the academic quality control which includes monthly monitoring of students presence and performance. The most common measures to implement it are weekly or monthly meetings of students with coordinators at the host institutions, monthly progress reports to the research supervisors at the home institutions, as well as communicating in the group in the social networks. On the scholarship holders' return to home universities local coordinators are to organize feedback sessions to next prospective programme beneficiaries.

\section{CONCLUSIONS}

Thus, it can be seen that Ukrainian professional education faces a number of challenges associated with international projects management. The main problem is connected with lack of project-writing teams, proficient in language and experienced in budget distribution. The next important thing is the necessity to make Ukrainian universities attractive as host institutions. And, finally there should be filled in the gap between university research and practice. These problems can be tackled with the help of academic mobility projects bringing best European practices to Ukraine. Perspectives for future researches may be the further study of international projects management.

\section{REFERENCES}

1. EUA. European University Association. (2015). Retrieved 1.10.2015 from : http://www.university-autonomy.eu/.

2. Erasmus Mundus - Integration of Neighbouring EasterN Regions through Cooperation in Higher Education. (2015). EMINENCE. Retrieved 1.10.2015 from : http://www.mundus.amu.edu.pl/EMINENCE.

3. EMINENCE Management. (2015). Retrieved 1.10 .2015 from : http://mundus.home.amu.edu.pl/EMINENCE_MANAGEMENT/app/auth/login.php.

4. EMINENCE Selection Process. (2015). Retrieved 1.10.2015 from :.http://mundus. home.amu.edu.pl/EMINENCE_MANAGEMENT/app/docs/list.php?no=03.

5. Брінь, П., Мушинська, Г. (2014). Управління міжнародними проектами у ВНЗ України [International Project Management in Ukrainian Higher Educational Establishments]. Вісник Національного технічного університету «ХПІ». Сер. : Актуальні проблеми розвитку украӥнського суспільства [Bulletin of National Technical University (KPI). Series: Topical Problems of Ukrainian Society Development], No 37, pp. 120-125 (in Ukrainian). 